II. Aus dem hygienischen Institut des Herrn Geheimrath Koch zu Berlin.

\section{Ueber Indol- und Phenolbildung durch Bacterien.}

Von Dr. A. Lewandowski, prakt. Arzte in Berlin.

Wie Kitasato und Th. Weyl ${ }^{1}$ ) fanden, bildet der auf Kochscher Fleischbrühe cultivirte Bacillus Tetani Indol und Phenol. Da nun aber bereits E. Baumann ${ }^{2}$ ) dem Phenol unter den Fäulnissproducten der Eiweisskörper begegnete, konnte die Phenolbildung keine specifische Function des Tetanusbacillus sein, wenn man nicht annehmen wollte, dass sich in der Mischung von Mikroorganismen, um welche es sich in den Baumann'schen Versuchen handelte, gerade der Bacillus Tetani vorhanden gewesen sei.

Ich habe nun auf Veranlassung und unter Leitung des Herrn Dr. Th. Weyl im hiesigen hygienischen Institut eine grosse Reihe von "Bacterien" auf ihre Fähigkeit, Indol und Phenol zu erzeugen, untersucht.

Als Nährboden diente mir, wie in den Weyl'schen Versucheu, die K o ch'sche Fleischbrühe. Die Culturen kamen nach 8-10tägigem Wachsthum zur Untersuchung, wenn sie sich bei Prüfung durch das Platteuverfahren als Reinculturen erwiesen hatten.

Zur Prüfung auf Indol und Phenol wurden jedesmal circa $250 \mathrm{ccm}$ der Cultur mit circa $50 \mathrm{ccm}$ starker Salzsäure destillirt. Da die gesuchten Stoffe leicht flüchtig waren, brauchten nur die ersten Fractionen untersucht zu werden. Gab das Destillat mit Bromwasser sofort oder nach kurzem Stehen einen flockigen krystallinischen Niederschlag, so war Phenol uachgewiesen. In einigen Fällen wurde der Bromniederschlag anch durch seinen Schmelzpuukt als Tribromphenol identificirt.

Zur Prüfung auf Indol versetzte ich circa $5 \mathrm{ccm}$ des Destillats mit circa $2 \mathrm{ccm}$ einer verdünnten Schwefelsäure (1:3) und 2-3 Tropfeu einer $0,1 \%$ igen Lösung von Natriumnitrit. Eine Rothfärbung bewies die Anwesenheit des gesuchten Stoffes.

Meine Resultate habe ich iu der folgenden Tabelle zusammengestellt.

\begin{tabular}{|c|c|c|}
\hline $\begin{array}{c}\text { Laufende } \\
\text { No. }\end{array}$ & $\mathrm{N}$ a $\mathrm{nl}$ e. & Bemerkungen. \\
\hline $\begin{array}{c}1 . \\
2 . \\
3 . \\
4 . \\
5 . \\
6 . \\
7 . \\
8 . \\
9 . \\
10 . \\
11 . \\
12 . \\
13 . \\
14 . \\
15 . \\
16 . \\
17 . \\
18 .\end{array}$ & 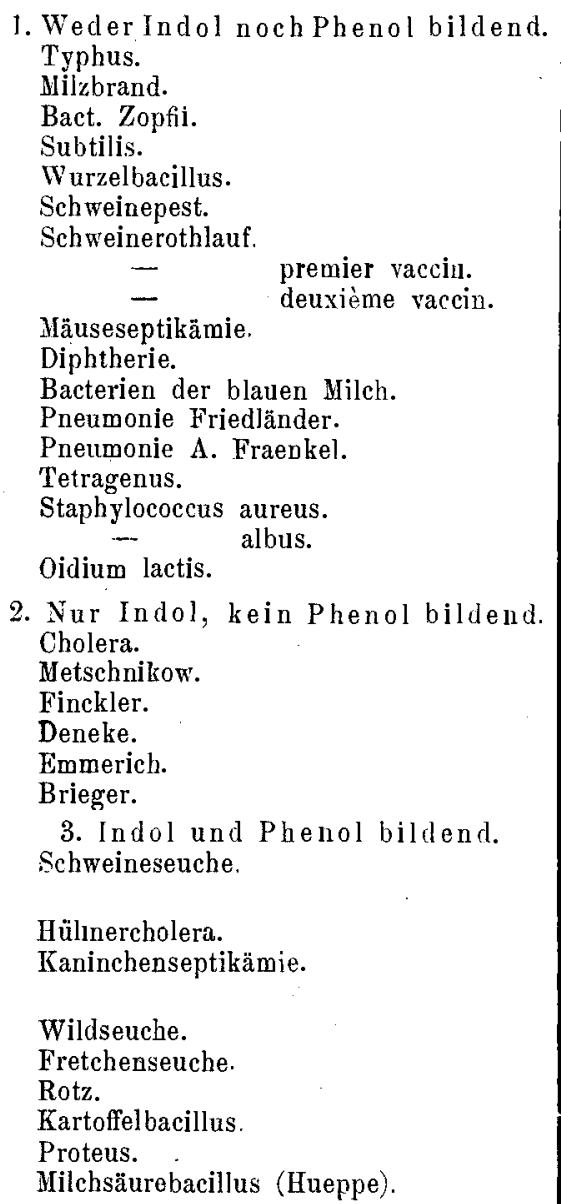 & 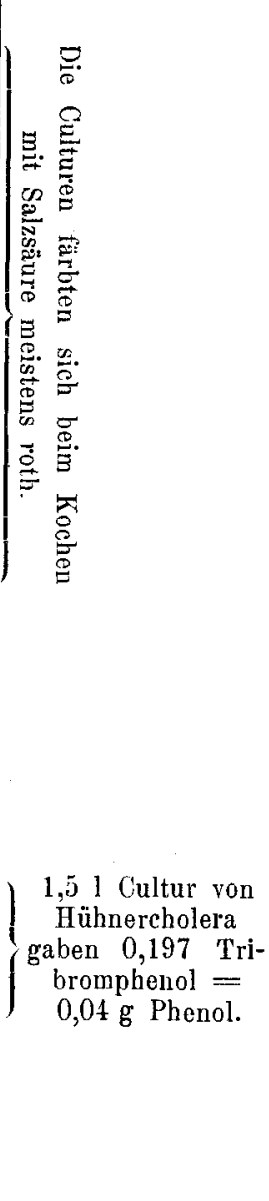 \\
\hline
\end{tabular}

Wie sich aus vorstehender Zusammenstelluug ergiebt, trat eine gleichzeitige Bildung von Indol und Phenol nur bei 9 von den 33 ïberhaupt untersuchten Mikroorganismen auf, während 6 nur

Zeitschr. f. Hygiene VIII., 409 (1890).

2) Zeitsch. f. physiolog. Chemie I., 60 (1877).
Indol, aber kein Phenol, 18 weder Indol noch Phenol bildeten. Dagegen wurde ausnahmslos Phenolbildung in denjenigen Fällen beobachtet, in welchen auch Indolbildung nachgewiesen wurde. Dies spricht für einen Zusammenhang beider Erscheinungen, der weiter untersucht $z u$ werden verdiente.

Bemerkenswerth scheint ferner, dass Schweinerothlauf und Schweinepest (Swineplague $=$ Swinpest) 1 ) weder Indol, noch Phenol erzeugeu, während die ihnen morphologisch so nahe stehenden Bacterien der Schweineseuche, Hühnercholera, Wildseuche, Fretchenseuche und Kaninchenseptikämie sowohl Indol als Phenol zu bilden vermögen. 